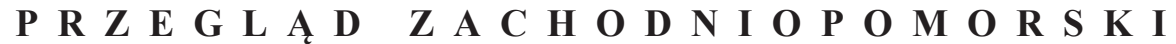 ROCZNIK XXX (LIX) ROK 2015 ZESZYT 1

$\begin{array}{llllllllllllllll}\mathbf{S} & \mathbf{T} & \mathbf{U} & \mathbf{D} & \mathbf{I} & \mathbf{A} & & \mathbf{I} & \mathbf{R} & \mathbf{O} & \mathbf{Z} & \mathbf{P} & \mathbf{R} & \mathbf{A} & \mathbf{W} & \mathbf{Y}\end{array}$

\author{
BARBARA ŻAKOWSKA \\ Szczecin
}

\section{Dzialalność DYdaKTYCzNA, WYCHOWAWCZA ORAZ OPIEKUŃCZA Szkoly MiędzynarodoweJ w Szczecinie W KONTEKŚCIE ROZWOJU SZKOLNICTWA NIEPUBLICZNEGO PO 1989 ROKU}

Słowa kluczowe: szkolnictwo niepubliczne, Społeczne Towarzystwo Oświatowe, demokratyzacja oświaty

Keywords: non-public (private) education, Educational Social Association, democratisation of education

\section{Przyczyny tworzenia szkół niepublicznych}

Przełom lat osiemdziesiątych i dziewięćdziesiątych XX wieku otworzył nowe możliwości, w których pluralistyczne społeczeństwa dostały prawa decydowania o kształcie otaczającego świata. W Polsce lato 1989 roku było znaczącym okresem, zwiastującym wielkie zmiany, które dotyczyły przebudowy wielu dziedzin życia społeczno-politycznego. Przede wszystkim transformacja ustrojowa doprowadziła do przekształcenia Polski w kraj demokratyczny. Częściowo wolne wybory do Sejmu i całkowicie do Senatu w 1989 roku oraz wybory prezydenckie w 1990 roku były efektem walki o niepodległość, wolność oraz niezależność. Kolejny krok reorganizacji państwa dotyczył transformacji gospodarki centralnie sterowanej w wolnorynkową. Od tej pory społeczeństwo miało prawo decydować m.in. o wysokości cen produktów oraz ich jakości, a jedynym czynnikiem regulującym była konkurencja oraz prawo popytu i podaży. Gospodarka rynkowa, 
w przeciwieństwie do gospodarki planowanej, wyróżniała się wolnością oraz niezależnością ${ }^{1}$.

Transformacja ustrojowa oraz gospodarcza często nacechowane były spontanicznością, żywiołowością i autonomią. Społeczeństwo oraz rządzący stanęli przed wielkim wyzwaniem poradzenia sobie z tak obszerną wolnością decydowania o kierunku rozwoju, gdzie przestają istnieć restrykcyjne wytyczne i z góry narzucone drogi postępowania. Lucyna Górska opisuje to w takich słowach:

w sytuacji „próżni instytucjonalnej” realizacja zadań napotyka na wiele przeszkód, widocznych szczególnie tam, gdzie skończyły się odgórne dyrektywy, które stanowiły podstawowy wyznacznik funkcjonowania jednostek i grup społecznych².

W świetle zmian ustroju i systemu gospodarczego nastał początek społeczeństwa obywatelskiego, które za sprawą swojej aktywności, samoorganizacji i dążeniu do wspólnego celu pokonuje kolejne szczeble rozwoju. Na początku lat dziewięćdziesiątych XX wieku wyzwolenie takiej aktywności i inicjatywy zauważalne było w wielu dziedzinach życia społecznego, w tym i w oświacie. Zmiany ustrojowe zapoczątkowane wyborami w czerwcu 1989 roku wpłynęły znacząco na funkcjonowanie oświaty w skali kraju, ale także regionów. Równocześnie z pojawieniem się pluralizmu politycznego, wolności słowa, nowego sposobu rządzenia krajem, wolności rynkowej, polska szkoła została pobudzona do organizacyjnych i merytorycznych zmian ${ }^{3}$.

W 1990 roku, ówczesny minister oświaty Henryk Samsonowicz podkreślał rolę demokratyzacji oświaty oraz samorządności, które były wspierane przez autonomię edukacji szkolnej. W liście ministra edukacji do dyrektorów szkół i nauczycieli zachęcał do autonomii, która oznaczała samodzielność podejmowania decyzji, ale również ponoszenia odpowiedzialności za efekty tych decyzji ${ }^{4}$.

Nadszedł czas, w którym rozpoczęto decentralizowanie oświaty oraz jej odideologizowanie. Był to moment przechodzenia z biurokratyczności do samorządności i autonomii szkoły oraz nauczycieli. Przywrócenie praw uczniom oraz

\footnotetext{
${ }^{1}$ J. Wasilewski, Ideat demokracji i jego ułomne wcielenia, w: Demokracja $w$ Polsce doświadczenia zmian, red. U. Jakubowska, K. Skarżyńska, Warszawa 2005, s 76.

${ }^{2}$ L. Górska, Wizje zawodu nauczyciela u progu trzeciego tysiaclecia, Szczecin 1995, s. 39.

${ }^{3}$ P. Bartnik, Przemiany w zachodniopomorskiej oświacie (1989-2007), w: Kazimierz Kozłowski, Pomorze Zachodnie w latach 1945-2010, t. I, Szczecin 2012, s. 188.

${ }^{4}$ B. Śliwerski, Problemy współczesnej edukacji. Dekonstrukcja polityki oświatowej III RP, Warszawa 2009, s. 61.
} 
zmiany w programach nauczania ukształtowały obraz szkoły otwartej, niejednoznacznej i demokratycznej. Szkoła zwolenników demokratyzacji, decentralizacji oraz uspołecznienia:

jest (ma być) instytucją oferującą uniwersalne wartości, umożliwiając uzyskanie podstaw wiedzy wraz ze sprawnościami niezbędnymi do pomyślnego funkcjonowania jednostki w świecie idei, ludzi, przyrody i rzeczy, nade wszystko stwarzając szanse samorealizacji, nieskrępowanego rozwoju osobowości, osiągania indywidualnych celów życiowych ${ }^{5}$.

Oczywiste, że zmiany te, pomimo dobrych chęci rządzących oraz środowiska nauczycielskiego, nie były łatwe do przeprowadzenia. Szkoła w nowej Polsce nie znała pojęcia demokratyczności, ponieważ przed wojną, ale także po niej, była pod ścisłą kontrolą państwa ${ }^{6}$. Ponadto, wprowadzona w życie Ustawa o systemie oświaty z 7 września 1991 roku, była podstawą do reformowania polskiej szkoły i początkiem drogi do demokratyzacji oświaty. Na II Ogólnopolskim Zjeździe Pedagogicznym w 1995 roku Profesor Mirosław Szymański oraz Profesor Zbigniew Kwieciński podkreślali, że „demokratyzacja na dłuższy lub krótszy czas nie może być zadekretowana, ale trzeba wciąż walczyć o jej urzeczywistnienie i udoskonalenie".

Społeczeństwo głodne stanowienia o sobie i realizacji siebie starało się wykorzystać nowe możliwości oraz istniejące podstawy prawne. Efektem aktywności i dążenia obywateli do zmiany polskiej oświaty było powstanie w 1987 roku Społecznego Towarzystwa Oświatowego (STO) ${ }^{8}$, które miało swoje liczne delegatury wojewódzkie i lokalne (koła). W deklaracji programowej z 22 stycznia 1989 roku Towarzystwo ogłosiło swoje cele i kierunek na przyszłość:

Społeczne Towarzystwo Oświatowe jest organizacją zrzeszającą wszystkich zainteresowanych kondycją polskiej oświaty i tworzeniem jej nowych, alternatywnych form. Należą do niego przede wszystkim rodzice i nauczyciele. Naczelnym zadaniem Towarzystwa jest prowadzenie wszechstronnych działań na rzecz poprawy możliwości edukacji dzieci i młodzieży, na rzecz uspołecznienia polskiego systemu

\footnotetext{
${ }^{5}$ T. Lewowicki, Przemiany w oświacie, Warszawa 1994, s. 86.

${ }^{6}$ J. Górniewicz, Szkoła a demokracja, „Wychowanie na Co Dzień” 1996, nr 6, s. 31-32.

${ }^{7}$ M.J. Szymański, Szanse i bariery tworzenia demokratycznej szkoły we współczesnym społeczeństwie, w: Szkoła, nauczyciele, uczniowie. Dyskusja o programie, metodzie i uczeniu sie w Europie, red. T. Gomuła, T. Dyrda, Radom-Kielce 2010, s. 18.

${ }^{8}$ Ustawa o stowarzyszeniach z 7.04.1989 r., Dz.U. 1989, nr 20, poz. 104.
} 
oświatowego oraz stworzenia możliwości wyboru różnych dróg kształcenia i wychowywania9.

Z inicjatywy STO zaczęło powstawać wiele szkół niepublicznych. Pod koniec 1989 roku, w celu wprowadzenia ładu podczas tworzenia się nowych placówek, Ministerstwo Edukacji Narodowej wydało rozporządzenie w sprawie zasad prowadzenia pedagogicznej działalności innowacyjnej w szkołach i placówkach oświatowo-wychowawczych ${ }^{10}$. Do czasu powstania Ustawy o systemie oświaty w 1991 roku zarządzenie to było prawną podstawą dla rozwoju niepublicznego szkolnictwa.

Już w 1988 roku dokonano próby utworzenia pierwszej szkoły społecznej w Krakowie. Jednak Minister Edukacji Narodowej Henryk Bednarski 20 lipca 1988 roku nie zezwolił na działalność tej placówki, tłumacząc, że pobieranie opłat za naukę uważa za sprzeczne z konstytucją. Decyzja została zaskarżona do Naczelnego Sądu Administracyjnego z uzasadnieniem, że istnienie szkolnictwa społecznego, autonomicznego i niezależnego od rządzących, jest cechą państwa demokratycznego ${ }^{11}$. W lutym 1989 roku NSA uchyliło decyzję MEN ${ }^{12}$. Sąd uzasadnienie wyroku oparł na Konstytucji PRL z 1952 roku, w której art. 72. głosił, że „obywatele Polskiej Rzeczypospolitej Ludowej mają prawo do nauki”", na Międzynarodowym Pakcie Praw Gospodarczych, Społecznych i Kulturalnych, uchwalonym przez Zgromadzenie Ogólne ONZ 16 grudnia 1966 roku i ratyfikowanym przez Polskę 3 marca 1977 roku $^{14}$. Na podstawie wymienionych aktów prawnych, Najwyższy Sąd Administracyjny uznał, że państwo zobligowane jest

${ }^{9}$ Deklaracja Programowa Społecznego Towarzystwa Oświatowego uchwalona przez I walne Zgromadzenie Członków Społecznego Towarzystwa Oświatowego z 22.01.1989 r., www.sto.org. pl/deklaracja-programowa (4.01.2014).

${ }^{10}$ Dz.U. MEN nr 7 z 1989 r. Zarządzenie w sprawie zasad prowadzenia pedagogicznej działalności innowacyjnej w szkołach i placówkach oświatowo-wychowawczych nr 62 z 16.11.1989 r.

${ }^{11}$ M. Makowska, Oświata niepubliczna jako forma aktywności obywatelskiej na Pomorzu Zachodnim po 1989 roku, w: W poszukiwaniu tożsamości. Od idei samorządności do samorzadzenia, red. A. Makowski, Szczecin 2011, s. 340.

${ }^{12}$ Wyrok NSA z 24.02.1989 r., I SA 1104/88, www.orzeczenia-nsa.pl/wyrok/i-sa-1104-88,oswiata_szkolnictwo_wyzsze_nauka_dzialalnosc_badawczo_rozwojowa_i_archiwa,4calf4.html (4.01.2014).

${ }^{13}$ Obwieszenie Przewodniczącego Rady Państwa z 16.02.1976 r. w sprawie ogłoszenia jednolitego tekstu Konstytucji Polskiej Rzeczypospolitej Ludowej uchwalonej przez Sejm Ustawodawczy z 22.07.1952 r., Dz.U. 1976, nr 7, poz. 36.

${ }^{14}$ Międzynarodowy Pakt Praw Gospodarczych, Społecznych i Kulturalnych otwarty do podpisu w Nowym Jorku 19.12.1966 r., Dz.U. 1977, nr 38, poz. 169. 
do stworzenia możliwości korzystania z bezpłatnej edukacji, ale jednocześnie nie ogranicza wyboru podjęcia edukacji w innej formie, w tym płatnej. Takie uzasadnienie dało początek legalnego tworzenia się szkół niepublicznych.

Z ramienia STO w roku szkolnym 1989/1990 zarejestrowano 32 szkoły, a w roku szkolnym 1990/91 liczba ich wzrosła do $179^{15}$. Powstanie szkół niepublicznych było triumfem demokracji, rodzeniem się nadziei na samorządność, ale także poprawą innych sfer życia społecznego. Został złamany monopol państwa w oświacie i powstała szansa na oddolne reformy edukacji. Szkoły niepubliczne przed 1991 rokiem, zwane często prywatnymi lub społecznymi, stały się wsparciem dla publicznej oświaty, pogrążonej w wielkim kryzysie ${ }^{16}$. Wyrosły z oczekiwań i marzeń społecznych, że będą lepsze od publicznych pod wieloma względami. Spodziewano się wysokiego poziomu nauczania, podmiotowego $\mathrm{i}$ indywidualnego podejścia do ucznia, interesujących zajęć szkolnych. Nie zapomniano też o lepszych warunkach pracy i płacy dla nauczycieli17.

Z początkiem tworzenia się szkół niepublicznych napotykano na przeszkody różnego rodzaju. Lokale, w których mieściły się te placówki, nie były wystarczająco wyposażone, przystosowane do pracy dydaktycznej, wychowawczej i opiekuńczej. Nauczyciele, często młodzi, zaraz po studiach, zastępowali niedoświadczenie w zawodzie swoim kreatywnym i otwartym myśleniem. Z badań Krzysztofa Kicińskiego wynika, że poparcie środowiska nie było jednoznaczne. Z końcem lat 80. i na początku lat 90. XX wieku przebadani nauczyciele w większości opowiedzieli się za szkolnictwem państwowym, jako dominującym w oświacie, a szkoły niepubliczne uznali jako uzupełnienie systemu ${ }^{18}$.

\footnotetext{
${ }^{15}$ Społeczne Towarzystwo Oświatowe, www.sto.org.pl/historia (4.01.2014).

${ }^{16}$ Ten obszar historii zgłębiany jest m.in. przez: B. Śliwerski, Problemy współczesnej edukacji. Dekonstrukcja polityki oświatowej III RP, Warszawa 2009; K. Kruszewski, Szkolnictwo polskie: „katolickie” czy „europejskie”. Rozpoznanie bojem, „Polityka” 1992, nr 25; M.J. Szymański, Kryzys i zmiana. Studia nad przemianami edukacyjnymi w Polsce w latach dziewięćdziesiatych, Kraków 2001.

${ }^{17}$ Por. A. Nalaskowski, Szanse szkoty z wyboru, Toruń 1995; J. Jung-Miklaszewska, D. Rusakowska, Szkoty społeczne in statu nascendi, Warszawa 1995; B. Przyborowska, Szkolnictwo niepubliczne w Polsce. Oczekiwania i rzeczywistość, Toruń 1997; A. Popławska, Idea samorzadności. Podmiotowość, autonomia, pluralizm, Białystok 2001.

${ }^{18}$ K. Kiciński, Wizje szkoły w społeczeństwach posttotalitarnych, Warszawa 1993, s. 20. Ponadto Renata Siemieńska rozpoczęła badania w 1990 r. analizujące opinie społeczne dotyczące idei niepaństwowego szkolnictwa. Badania obejmowały skład społeczny szkół niepublicznych, oferty edukacyjnej, promowanie wartości i postaw. Wyniki z Warszawy (duża aglomeracja) wskazują zadowolenie rodziców z wyboru szkoły, wskazują wyższość szkół niepublicznych na publicznymi, podkreślają lepsze warunki do nauki. Szkoły niepubliczne w mniejszych aglomeracjach
} 
$\mathrm{Na}$ początku lat 90 . XX wieku, na mocy Ustawy o systemie oświaty z 7 września 1991 roku uregulowano tworzenie szkół niepublicznych. Zgodnie z ustawą szkoły płatne - społeczne i prywatne - zostały nazwane niepublicznymi. Powyższa ustawa, obwiązująca do dziś, wspiera istnienie i tworzenie szkół niepublicznych m.in. przez dotację budżetową ${ }^{19}$, nadawanie szkole niepublicznej prawa szkoły publicznej (co umożliwia wystawianie świadectw honorowanych przez szkoły publiczne) oraz udostępnianie przenoszenia ucznia ze szkoły niepublicznie do publicznej ${ }^{20}$.

Lata 90. XX wieku stały się wyjątkowym czasem dla tworzenia się szkół niepublicznych w całej Polsce. Również na terenie Szczecina zaczęły prowadzić swoją dzielność pierwsze tego typu placówki. 1 września 1989 roku, z inicjatywy Społecznego Towarzystwa Oświatowego, powstała pierwsza szkoła niepubliczna - Szkoła Podstawowa Społecznego Towarzystwa Oświatowego w Szczecinie ${ }^{21}$. Kolejne lata XX wieku, jak również początek XXI wieku, pokazują wzrost liczby szkół niepublicznych na wszystkich szczeblach kształcenia. Jak widać na poniższym wykresie (rys. 1), w roku szkolnym 2009/2010 licea niepubliczne dominowały na terenie całej Polski. W województwie mazowieckim szkoły niepubliczne wszystkich szczebli stanowiły 15\% ogółu szkół. Województwo to charakteryzuje się największą liczbą niepublicznych szkół podstawowych, gimnazjalnych oraz liceów. Podobna sytuacja dotyczy województwa pomorskiego, które przewyższa średnią liczbę szkół niepublicznych wszystkich typów występujących w całej

zostały ocenione mniej pozytywnie, jako zjawisko niekorzystne, promujące snobizm ekonomiczny, aczkolwiek większość badanych uznała te placówki za lepsze od szkół państwowych, E. Putkiewicz, A. Wiłkomirska, Szkoły publiczne i niepubliczne. Porównanie środowisk edukacyjnych, Warszawa 2004, s. 13.

${ }^{19}$ Wysokość dotacji z budżetu państwa dla szkół niepublicznych to sprawa zasługująca na specjalną uwagę. Początkowo (w Ustawie o systemie oświaty z 1991 r.) szkoły uzyskały dotację „do 50\%” wydatków na jednego ucznia w szkołach publicznych - przepis nieprecyzyjny i niekorzystny, w praktyce bowiem utrudniał szkołom egzekwowanie ustawowej dotacji. Od 09.1992 r. na mocy Rozporządzenia MEN zapewniona została dotacja „w wysokości 50\%” wydatków w szkołach publicznych na jednego ucznia. W 1995 r. zapis ten udało się wprowadzić do Ustawy o systemie oświaty, a w roku 1998 zmienić go na „w wysokości nie niższej niż 50\%”. Dopiero w 2000 r. doprowadzono do zapisu o dotacji w wysokości $100 \%$ subwencji, www.sto.org.pl/historia $(18.02 .2014)$

${ }^{20}$ Ustawa o systemie oświaty z 7.09.1991 r., Dz.U. 1991, nr 95, poz. 425.

${ }^{21}$ Szkoła Podstawowa Społecznego Towarzystwa Oświatowego w Szczecinie została utworzona za zgodą MEN-DKO 1-0 145/17/89/WP z 26.06.1989 r. 1.09.1989 r. odział „0” oraz klasy I-III rozpoczęły swoją działalność. Decyzją MEN WSN-0145-246/91/KPS rozszerzono działalność na klasy IV-VIII. Obecnie szkoła nosi nazwę Społeczna Szkoła Podstawowa im. Noblistów Polskich, www.sto.szczecin.pl/o-nas/o-nas (18.02.2014). 
Polsce. Biorąc pod uwagę czynnik ekonomiczny i średnie miesięczne zarobki, można się spodziewać, że te dwa najbogatsze województwa będą miejscem korzystnym do rozwoju pomiotów niepaństwowych ${ }^{22}$. Kolejnym ważnym ośrodkiem dla szkolnictwa niepublicznego jest województwo zachodniopomorskie. Pod względem dobrobytu i rozwoju gospodarczego obszar ten nie plasuje się na pierwszych miejscach wśród rankingów, dlatego też może zdumiewać fakt, że na tym obszarze funkcjonuje największa liczba liceów niepublicznych - jest ich aż 27\% w stosunku do ogółu liceów w tym regionie. Niepublicznych szkół podstawowych oraz gimnazjów jest również znacząco więcej w porównaniu do średniej występującej na całym obszarze Polski. Z kolei niewiele szkół nowego typu powstało w województwie podkarpackim oraz świętokrzyskim -notuje się tam zaledwie nieco powyżej 1\% tego typu placówek.

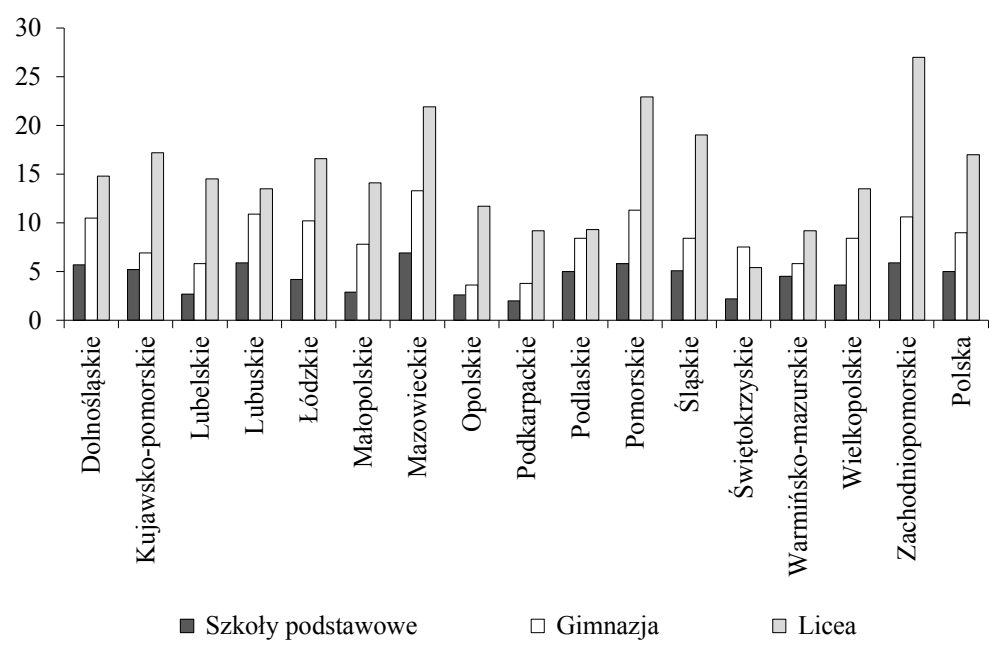

Rys. 1. Szkoły niepubliczne w stosunku do ogółu szkół według województw

Źródło: Oświata i wychowanie w roku szkolnym 2009-2010, Warszawa, www.stat.gov.pl/cps/rde/ xbcr/gus/PUBL_e_education_in_2009-2010_school_year.pdf; Rocznik statystyczny Rzeczypospolitej Polskiej 2010, w: M. Makowska, Oświata niepubliczna ..., s. 347.

\footnotetext{
${ }^{22}$ Raport firmy Sedlak \& Sedlak ukazuje zamożność w poszczególnych województwach, Mapa wynagrodzeń Polaków w 2010 roku, Kraków 2011, http://hrstandard.pl/download/RAPORT_ Mapa_wynagrodzen_Polakow.pdf (5.01.2014).
} 
Obecnie w Szczecinie prowadzi swoją działalność 11 podstawowych szkół niepublicznych, 13 niepublicznych szkół gimnazjalnych oraz 36 niepublicznych szkół licealnych ${ }^{23}$. Jedną z nich, która łączy w sobie wszystkie trzy szczeble kształcenia, jest Szkoła Międzynarodowa w Szczecinie.

\section{Początki Szczecin International School}

Szkoła Międzynarodowa (Szczecin International School) należy do szkół niepublicznych, powstałych już w XXI wieku. Szkoła ta ze względu na swoją wielokulturowość oraz bardzo głębokie doświadczenie w realizowaniu programów międzynarodowych jest szczególnym zjawiskiem nie tylko na terenie Szczecina, ale także Polski. Powstanie Szkoły Międzynarodowej w Szczecinie było spowodowane wieloma czynnikami gospodarczymi oraz politycznymi w naszym regionie.

Historia Szkoły Międzynarodowej zaczyna się po 1999 roku, kiedy to w Szczecinie, po tym, jak Polska wstąpiła do NATO (Sojusz Północnoatlantycki), zaczął stacjonować Wielonarodowy Korpus Północny Wschód - The Multinational Corps North-East (MNC NE). W Korpusie pracują żołnierze z różnych zakątków świata, m.in. z: Niemiec, Danii, Estonii, USA i Polski. Praca i życie członków kadry wojskowej MNCNE polega na cyklicznym przemieszczaniu się z jednej jednostki do drugiej. Żołnierze przyjeżdżają z żonami i dziećmi na kontrakty od dwóch do czterech lat. W związku z tym, jednym z podstawowych warunków utworzenia korpusu było stworzenie placówki edukacyjnej dla dzieci żołnierzy. Pomysłów na miejsce tworzenia takiej szkoły było wiele. Oczekiwania korpusu w stosunku do szkoły, w której miały się kształcić dzieci żołnierzy z wielu krajów, były jasne i nieugięte. Potrzebna była szkoła, która spełniałaby nie tylko możliwość nauczania w języku angielskim, ale także zapewniała edukację na wszystkich poziomach kształcenia, od szkoły podstawowej po liceum ogólnokształcące. Pierwszym rozwiązaniem miała być szkoła językowa Perseverantia. Nie miała ona jednak możliwości nauczania na wszystkich poziomach kształcenia. Ostatecznie polskie Ministerstwo Obrony wybrało spółkę British School, która miała doświadczenie w prowadzeniu tego typu placówki w Piasecznie

\footnotetext{
${ }^{23}$ Urząd Miasta Szczecin, Wydział Oświaty, www.bip.um.szczecin.pl/umszczecinbip/chapter_11026.asp (1.07.2014).
} 
k. Warszawy oraz w Poznaniu. Kierownikiem spółki, a zarazem dyrektorem British School w Szczecinie, była Krystyna Mazowiecka ${ }^{24}$.

W sytuacji, gdy wybrana została już jednostka prowadząca szkołę, nastała potrzeba znalezienia budynku, w którym dzieci oficerów mogłyby zacząć pierwszy rok szkolny. Pomysły wykorzystania budynków szkolnych przy ul. Jagiellońskiej w Szkole Podstawowej nr 58 oraz przy ul. Mikołajczyka w Szkole Podstawowej nr 72 nie spotkały się z aprobatą ówczesnego generała Henrika Ekmanna. Szkoły były położone w centrum miasta, a wkoło było mało zieleni. Generał szukał szkoły przyjaznej, bezpiecznej i z dala od gwaru miejskiego. Budynek SP nr 36 zdecydowanie przypadł do gustu dowódcy. Szkoła mieściła się na osiedlu arkońskim, ale nie tylko miejsce i otoczenie zadecydowało o podjęciu pozytywnej decyzji. Ze względu na to, że na osiedlu arkońskim panował niż demograficzny i nowo powstała SP nr 68 ściągała do siebie uczniów, SP nr 36 miała problemy $\mathrm{z}$ zapełnieniem sal lekcyjnych oraz utrzymaniem budynku ${ }^{25}$. Efektem podjętych decyzji było zajecie przez uczniów z Korpusu NATO pierwszego piętra, na którym było osiem sal lekcyjnych, w tym pracownia komputerowa oraz fizyczno -chemiczna. Ponadto dzieci z NATO korzystały wspólnie z uczniami z SP nr 36 ze stołówki, sali gimnastycznej oraz boiska ${ }^{26}$.

Inauguracja pierwszego roku szkolnego odbyła się we wrześniu 1999 roku, na uroczystość zaproszeni zostali szefowie korpusu oraz dowódca - generał Henrik Ekmann. Od początku szkoła zaczęła działać w programie brytyjskim dla grupy przedszkolnej, szkoły podstawowej, gimnazjum oraz liceum. W roku szkolnym 1999-2000 uczyło się w niej 84 uczniów, przede wszystkim z Polski, Danii i Niemiec, ale także z dalszych zakątków świata, np. Kanady, Anglii, Węgier, a nawet z Nowej Zelandii. British School była otwarta nie tylko na dzieci oficerów, mogły do niej uczęszczać dzieci rodziców innych profesji, chociaż przeszkodą mogło być wysokie czesne. Za dziecko przedszkolne trzeba było zapłacić 3500 dolarów rocznie, natomiast za maturzystę nawet 10 tys. dolarów rocznie ${ }^{27}$. W takich okolicznościach rozwijała się idea szkoły międzynarodowej w Szczecinie.

British School zaczęła borykać się z poważnymi problemami finansowymi. Z powodów ekonomicznych oraz organizacyjnych w 2002 roku potrzebne były

\footnotetext{
${ }^{24}$ Wywiad z Panią Marią Hajdul, Zastępcą Dyrektora Wydziału Oświaty Urzędu Miasta Szczecina w latach 1994-2001 (z 1.07.2014 r.).

${ }^{25}$ Ibidem.

${ }^{26}$ D. Kozakiewicz, Szkoła kolorowa - różnonarodowa, „Głos Szczeciński” 18-19.09.1999 r.

${ }^{27}$ Ibidem.
} 
działania wspierające utrzymanie tak ważnej politycznie i gospodarczo placówki edukacyjnej. Z pomocą wystąpiła Wyższa Szkoła Integracji Europejskiej (WSIE). 19 lipca 2002 roku, po wygranym przetargu, WSIE oraz Inbit Polska zostały organem założycielskim Szkoły Międzynarodowej w Szczecinie. Po podpisaniu kontraktu pomiędzy dowództwem Korpusu, reprezentowanym przez gen. Schneidera, ówczesnego Rektora WSIE prof. Zygmunta Meyera, Prezydenta Miasta Szczecina Edmunda Runowicza oraz Kuratora Oświaty Jerzego Kotlęgi w Szczecinie, 2 września 2002 roku szkoła rozpoczęła swoją działalność28. Stanowisko rektora objął Piotr Wahl, a kierownictwo szkoły i odpowiedzialność za rozwój tej placówki powierzone zostały Marii Sawce. Pierwszą siedzibą szkoły był budynek przy ulicy Adama Mickiewicza 49. Pod skrzydłami WSIE Szkoła Międzynarodowa rozwijała swoją działalność. Od stycznia 2009 roku szkoła działa pod patronatem Stiftung \& Bildung und Handwerk z siedzibą w Paderborn w Niemczech. Niemiecka fundacja zintegrowała Szczecin International School ze swoim związkiem instytucji edukacyjnych. W tym samym roku szkoła zmieniał swoja nazwę na SIS Spółka z o.o. z siedzibą przy ulicy Starzyńskiego 3-4. Od października 2013 roku szkoła mieści się w budynku byłego Liceum Ogólnokształcącego nr 8 przy ulicy Królowej Jadwigi 27.

Społeczność uczniowską tworzą nie tylko dzieci żołnierzy z Międzynarodowego Korpusu NATO w Szczecinie, ale także dzieci polskiego pochodzenia oraz dzieci z różnych zakątków świata, których rodzice postanowili osiedlić się w Szczecinie i pracują tutaj lub prowadzą prywatne przedsiębiorstwa. Szkoła uczy na wszystkich szczeblach edukacji, od przedszkola po liceum ogólnokształcące. W roku szkolnym 2012-2013 w szkole uczyli się przedstawiciele 13 narodowości: Niemcy, Polacy, Litwini, Estończycy, Duńczycy, Japończycy, Chińczycy, Belgowie, Słowacy, Słoweńcy, Rosjanie, Rumuni, Czesi. Na poziomie szkoły podstawowej było 89 uczniów, w gimnazjum 27, w liceum 13, łącznie - 132 uczniów w tej wielonarodowej społeczności ${ }^{29}$.

\footnotetext{
${ }^{28}$ Porozumienie wstępne z 20.07.2002 r. między Dowódcą Wielonarodowego Korpusu Północny Wschód (reprezentującym rodziców z Kwatery Głównej Korpusu), Zachodniopomorskim Kuratorem Oświaty, Prezydentem Miasta Szczecina a Wyższą Szkoła Integracji Europejskiej w sprawie utworzenia Międzynarodowej Szkoły w Szczecinie, Archiwum Szkolne.

${ }^{29}$ Lista uczniów w roku szkolnym 2012-2013, Archiwum szkolne.
} 


\section{Organizacja szkoły}

Szczecin International School jest placówką niepubliczną z prawami szkoły publicznej, dzięki czemu placówka ma prawo do wydawania świadectw i dyplomów państwowych. Ustawa o systemie oświaty z 7 września 1991 roku stanowi, że szkoła niepubliczna może mieć prawa szkoły publicznej, jeśli:

- realizuje programy nauczania uwzględniające podstawę programową kształcenia ogólnego,

- realizuje zajęcia edukacyjne w cyklu nie krótszym oraz w wymiarze nie niższym niż łączny wymiar obowiązkowych zajęć edukacyjnych określony w ramowym planie nauczania szkoły publicznej danego typu,

- realizuje ustalone przez ministra edukacji narodowej zasady oceniania, klasyfikowania i promowania oraz przeprowadzania egzaminów i sprawdzianów, z wyjątkiem egzaminów wstępnych,

- prowadzi dokumentację przebiegu nauczania ustaloną dla szkół publicznych,

- zatrudnia nauczycieli obowiązkowych zajęć edukacyjnych, z kwalifikacjami określonymi dla nauczycieli szkół publicznych (Rozporządzenie MENiS z 10.09.2002 r. w sprawie szczegółowych kwalifikacji wymaganych od nauczycieli oraz określenia szkół i wypadków, w których można zatrudnić nauczycieli niemających wyższego wykształcenia lub ukończonego zakładu kształcenia nauczycieli, Dz.U. z 23.09.2002 r., nr 155, poz. 1288) ${ }^{30}$.

Organem prowadzącym szkołę jest SIS Sp. z o.o. z siedzibą w Szczecinie. We wszystkich sprawach związanych z wykonywaniem obowiązków organu prowadzącego, szkołę reprezentuje prezes spółki. Organami szkoły są: dyrektor, Rada Pedagogiczna, Samorząd Uczniowski oraz Rada Szkoły ${ }^{31}$. Dyrektorem oraz zarządcą SIS jest Maria Sawka, oprócz której kierownicze stanowiska zajmują wicedyrektor oraz koordynatorzy. Każdy poziom kształcenia, od szkoły podstawowej po liceum ogólnokształcące, ma swojego koordynatora, odpowiedzialnego za realizację koncepcji dydaktycznych i wychowawczych na danym poziomie. Pierwszym koordynatorem na poziomie szkoły podstawowej była Anna Brooks (Wielka Brytania), na poziomie gimnazjum - Brian Walsh (Irlandia), a na poziomie liceum - Jeremy Clark (Wielka Brytania). Obecnie role te sprawowane są przez Diane Howlett (Kanada) na poziomie liceum, Kerstin Walter (Niemcy) na

\footnotetext{
${ }^{30}$ Ustawa o systemie oświaty z 7.09.1991 r., Dz.U. 1991, nr 95, poz. 425.

${ }^{31}$ Statut szkoły podstawowej, rozdz. 3, par. 3.
} 
poziomie gimnazjum oraz Agnieszkę Lal (Polska) w szkole podstawowej. Funkcję wicedyrektora piastuje Katarzyna Stütz ${ }^{32}$.

\section{Działalność dydaktyczna}

Szkoła Międzynarodowa, ze względu na swój wielonarodowy charakter, operuje w procesie kształcenia programami międzynarodowymi, nie zapominając przy tym o realizowaniu polskiej podstawy programowej na wszystkich szczeblach kształcenia. Zajęcia w SIS prowadzone są w systemie klasowym - maksymalna liczba uczniów nie powinna przekraczać 15 osób. Lekcje prowadzone są w systemie blokowym, jeden blok trwa 80 minut. W ciągu jednego dnia uczniowie uczestniczą w 4-5 blokach $^{33}$.

Statut szkoły stanowi, że obowiązującym dokumentem na poziomie szkoły podstawowej jest Podstawa programowa zatwierdzona przez MEN, rozszerzona o program International Primary Curriculum (IPC). Dodatkowo, szkoła zapewnia uczniom polskim realizację podstaw programowych, rozszerzonych o nauczanie dwujęzyczne ${ }^{34}$. Program międzynarodowy IPC składa się z 70 bloków tematycznych i obejmuje przedmioty ścisłe, historię, geografię, sztukę, informatykę, wychowanie fizyczne, muzykę i wychowanie dziecka w społeczności międzynarodowej. Tożsamy program obowiązuje w brytyjskich szkołach, jak również w wielu zakątkach całego globu. Program oparty jest na bardzo zróżnicowanej tematyce, która dotyczy życia codziennego. Jest to praktyczne podejście do uczenia się i przyswajania wiedzy. Dzieci pracują głównie metodą projektu i działań praktycznych, duży nacisk kładzie się na kreatywność ucznia, jak również na bezpośrednie poznanie otaczającego świata. Zdarza się, że w jednej klasie uczą się przedstawiciele od czterech do pięciu różnych narodowości. Bywa, że są uczniowie, którzy nie mówią po angielsku, ale mimo to stosunkowo szybko przystosowują się do nowej sytuacji dzięki wsparciu środowiska nauczycielskiego oraz rodziców.

Główną metodą wykorzystywaną podczas pracy w tak zróżnicowanych kulturowo klasach jest metoda praktyczna, dzięki której uczniowie poznają otaczający ich świat. Często przez takie działanie i dążenie do wspólnego celu pozwalamy przeciwstawić się egocentryzmowi czy uprzedzeniom. Ponadto praca w zespole nad projektem pozwala dzieciom zgłębiać wiedzę i wykorzystywać ją

\footnotetext{
${ }^{32}$ Kroniki Szczecin International School.

${ }^{33}$ Statut szkoły podstawowej, rozdz. 12.

${ }^{34}$ Statut szkoły podstawowej, rozdz. 5, par. 9, 10.
} 
w praktyce. W programie International Primary Curriculum, na każdym kroku sygnalizowane jest rozwijanie umiejętności interpersonalnych i komunikacyjnych. Prezentowane treści dotyczą wielu kultur, różnych społeczności. Program zachęca do zgłębiania kultury regionu, ale także wejścia w głąb kultury każdego członka grupy. Wielokrotnie powtarzana jest potrzeba zwrotu w stronę „home and host countries"35. Dla przykładu, nauczyciel w II klasie szkoły podstawowej, wraz z uczniami zajmuje się tematem o żywieniu. Oczywistym elementem tego zagadnienia będzie rozmowa, analiza, prezentacja, degustacja jedzenia z regionu czy kraju, z którego pochodzą uczniowie. Dodatkowym atutem program IPC jest to, że jest on niejednoznaczny i pozostawia wiele miejsca na kreatywność nauczyciela. Konstrukcja programu oparta jest na przedstawieniu celów, do jakich powinien dążyć nauczyciel, natomiast samo działanie i zorganizowanie lekcji zależy całkowicie od prowadzącego zajęcia. Jest to zadanie bardzo wymagające i odpowiedzialne, ale sprzyjające kreatywnemu myśleniu, otwartości i tolerancji dla inności. Dlatego też program IPC bardzo dobrze sprawdza się w nauczania wielokulturowym. Ponadto na poziomie szkoły podstawowej nauczyciele odznaczają się kreatywnością i innowacyjnością w tworzeniu nowych rozwiązań urozmaicających program nauczania. Realizacja projektów „Reading Buddies”, „Home Reading” oraz „Individual Reading”36 to dobry przykład na to, że czytanie może łączyć się z przyjemnością i nawiązywaniem dobrych relacji.

Na poziomie gimnazjum realizowana jest polska podstawa programowa równolegle z międzynarodowym programem Cambridge International Examinations (CIE), który kończy się egzaminem z międzynarodowym certyfikatem - International General Certificates of Secondary Education (IGCSE). W klasach od M1 (VI kl. SP) do M3 (II kl. G) uczniowie realizują poziom (key stage 3), który jest kontynuacją międzynarodowego programu szkoły podstawowej (IPC) i prowadzi do dwuletniego kursu International General Certificate of Secondary Education (IGCSE) dla klas M4 do D1 (III kl. G - I kl. LO). Kurs ten kończy się oficjalnym

\footnotetext{
${ }^{35}$ International Primary Curriculum, www.greatlearning.com/ipc/ (7.12.2013); „,home and host countries" - kraje naszych domów i gospodarzy.

36 „Reading Buddies” - czytanie koleżeńskie, polega na łączeniu uczniów w grupy, w których uczniowie starsi czytają wspólnie z młodszymi krótkie opowiadania. „Home Reading” - czytanie w domu, polega na cotygodniowym wypożyczaniu książki z zasobów anglojęzycznej literatury przeznaczonej dla dzieci, a następnie pisemnym odpowiedzeniu na pytania. „Individual Reading” - czytanie indywidualne $\mathrm{z}$ nauczycielem lub z rodzicem zaangażowanym w proces edukacyjny danej klasy. Czytanie odbywa się raz w tygodniu w klasach $0-3$. Każde dziecko ma szanse na rozwijanie umiejętności czytania w języku angielskim pod kątem wymowy oraz zrozumienia tekstu czytanego.
} 
egzaminem z wybranych pięciu przedmiotów. Uczniowie podejmujący naukę na poziomie gimnazjum w SIS zdają dobrowolnie egzaminy IGSCE, które w przyszłości pozwalają na swobodną kontynuację nauki w ojczystych krajach. Aby zapewnić wysoki poziom i równowagę w procesie nauczania, uczniowie, którzy nie przystępują do oficjalnej części egzamin, uczestniczą w wewnętrznych egzaminach końcowych na poziomie IGCSE. Ponadto w procesie kształcenia oferuje się uczniom program nauczania języków ojczystych: polskiego, niemieckiego oraz duńskiego. Programy te skorelowane są narodowymi programami nauczania języków ojczystych ${ }^{37}$.

Od 29 marca 2005 roku SIS jest także członkiem jednej z najbardziej znanych i poważnych organizacji edukacyjnych - IBO (International Baccalaureate Organization) z siedzibą w Genewie. International Baccalaureate Organization zrzesza 1597 szkół w 122 krajach świata i około 200 tys. uczniów. Matura IB stanowi ekwiwalent matury polskiej i nie wymaga nostryfikacji. W ostatnim roku, kończącym edukację w szkole średniej w systemie brytyjskim, uczniowie przystępują do egzaminu maturalnego IB (International Baccalaureate), składającego się z pięciu grup przedmiotowych. Uczniowie mogą wybierać takie przedmioty, jak: nauki ścisłe, języki i przedmioty humanistyczne. Pozytywne zdanie egzaminu IB z odpowiednią liczbą punktów umożliwia wstęp na renomowane uczelnie na całym świecie bez dodatkowych egzaminów. Ponadto, jest to bardzo wymagający międzynarodowy program maturalny, który promuje międzykulturowe zrozumienie oraz szacunek, nie jako alternatywa dla poczucia tożsamości kulturowej i narodowej, ale jako niezbędny element życia w XXI wieku ${ }^{38}$.

W literaturze analizującej nauczanie międzykulturowe wiele mówi się o języku. Marta Torenc podkreśla, że: „poznawanie języków obcych to jednocześnie poznawanie innych kultur, zaś poznawanie innych kultur jest nierozerwalnie związane z poznawaniem języków"39. Dlatego nie można mówić o kulturze pomijając rolę języka. Zdzisław Aleksander zauważa, że: ,język, jako twór społeczny jest nieodłączną częścią cywilizacji i kultury danego społeczeństwa. Odzwierciedlają się w nim różnice w sposobie widzenia rzeczywistości pozajęzykowej, a także wzorce i normy zachowania" ${ }^{\prime 40}$. Edward Sapir podkreśla rolę języka jako

\footnotetext{
${ }^{37}$ Program nauczania w gimnazjum SIS, Archiwum Szkolne.

${ }^{38}$ Program nauczania w liceum SIS, Archiwum Szkolne

${ }^{39}$ M. Torenc, Nauczanie międzykulturowe - implikacje glottodydaktyczne, Wrocław 2007, s. 9.

${ }^{40}$ Z. Aleksander, Elementy lingworealioznawcze w nauczaniu j. rosyjskiego, Warszawa 1982 s. 5.
} 
przewodnika po rzeczywistości społecznej, jako narzędzie komunikacji oraz system symboli, który warunkuje zachowanie, myślenie i wyrażanie emocji ${ }^{41}$. W Szkole Międzynarodowej w Szczecinie język jest przewodnikiem po kulturze. Językiem codziennego użycia jest język angielski, dla większości - język obcy. Bez wątpienia język jest narzędziem każdego członka tej społeczności, dzięki któremu uczniowie, nauczyciele i rodzice mogą mówić o sobie i do siebie. Dla każdego ważny jest jednak język ojczysty, który znamy od urodzenia, którym się porozumiewamy $\mathrm{w}$ trakcie dojrzewania, w którym naturalnie myślimy i wyrażamy nasze emocje - który nie może więc być w żaden sposób pominięty w procesie edukacji. W SIS uczniowie mają wiele możliwości mówienia własnym głosem. Uczniowie z Polski, Niemiec i Dani mają zajęcia z języka ojczystego trzy razy w tygodniu po 80 minut, w ramach programu kształcenia. Nie sposób zorganizować dla tylu narodowości zajęć z każdego języka ojczystego, ale nie chcąc pozbawić szans na rozwój w tym zakresie, szkoła daje możliwość nauczania języka ojczystego w szkole (w ramach zajęć) przez matki lub ojców. Z takiej ewentualności z radością korzysta coraz więcej rodziców.

\section{Działalność wychowawcza i opiekuńcza}

O wychowaniu w szkole mówi się dużo i niejednokrotnie można spotkać się ze stwierdzeniem, że wychowanie jest najtrudniejszym przedmiotem w szkole. Przytoczę słowa wieloletniej nauczycielki oraz dyrektorki jednej ze szczecińskich szkół, która przywiązuje wielką wagę do procesu wychowania: „Najlepszą regułą w wychowaniu jest brak reguł”, gdzie brak reguł nie oznacza braku wartości, jest tylko postawą wychowawcy w procesie kształcenia. Wychowawca nie nakazuje uczniom, jacy mają być, ale stwarza sytuacje, w których wychowanek może wykazać się koleżeństwem, uczciwością czy wrażliwością. Wychowanie to także proces bardzo delikatny, podczas którego tworzą się więzi bardzo subtelne. Więzi te dotyczą relacji nauczyciel-uczeń. Kontakt ten jest wyjątkowy i twórczy, ale bardzo łatwo go zniszczyć. Dlatego należy pamiętać, jak ważna jest osobowość nauczyciela, jego autentyczność, wiarygodność oraz jego kompetencje, dzięki czemu pedagog może zdobyć zaufanie ucznia, a to jest pierwszy krok ku wychowaniu ${ }^{42}$.

${ }^{41}$ E. Sapir, Kultura, język, osobowość, Wybrane eseje, Warszawa 1978, s. 89.

${ }^{42}$ H. Bartnik, O wychowaniu, w: Szkołe tworzy człowiek, red. P. Migdalski, Szczecin 2012, s. $157-160$. 
Minister Anna Radziwiłł wspominała także o pokorze wychowawcy mówiąc:

wychowawca musi pogodzić się z faktem, że rzadko zobaczy dosłowne „wyniki” swoich zabiegów i rzadko będzie zadowolony z jakości swojej pracy, ale jednocześnie, jak każdy człowiek, potrzebuje akceptacji ze strony innych ludzi. K. Brandys wspominając szkoły w „Małej Księdze” pisze o swoich nauczycielach - ich obowiązkiem było nas uczłowieczyć, naszym - dać im to ze sobą uczynić43.

Działalność wychowawcza szkoły jest niezmiernie ważna i wymaga odpowiedniej organizacji. W każdej szkole tworzy się program wychowawczy, który ukazuje zakres działań i metod wychowawczych, które odpowiadają potrzebom uczniów, wynikają ze środowiska lokalnego, ale także dostosowane są do możliwości nauczycieli i biorą po uwagę ich doświadczenie.

Ponieważ Szkoła Międzynarodowa pełna jest inności i różnorodności, przywiązuje się w niej szczególną wagę do procesu wychowawczego oraz opiekuńczego. Pierwszym krokiem zbliżającym członków międzynarodowego społeczeństwa oraz rozpoczynającym międzynarodowy dialog jest możliwość zapoznania się $\mathrm{z}$ inną kulturą dzięki obchodzeniu świąt $\mathrm{w}$ różnych terminach i w różnej oprawie. Wszystko to prowadzi do zrozumienia i zaakceptowania różnicy w codziennym rytuale każdego z członków szkolnej, wielokulturowej społeczności. Ta wiedza, zdobyta przez obydwie strony, jest niezmiernie ważna do budowania akceptacji i dialogu. W szkole obchodzony jest wraz z żołnierzami NATO Octoberfest, duńskie święto Santa Lucia, jak również religijne święto Whit Monday. Ponadto, uczniowie zapoznawani są z tradycją, historią i kulturą Polski i regionu, obchodząc m.in. Dzień Niepodległości czy też zwiedzając zabytki i ciekawe miejsca w okolicy. Kolejnym, bardzo pozytywnym działaniem sprzyjającym interakcji międzykulturowej w szkole, jest coroczny dzień integracyjny. $\mathrm{Z}$ początkiem każdego nowego roku szkolnego rodzice, uczniowie, nauczyciele oraz dyrekcja spotkają się, aby wspólnie spędzić czas na neutralnym gruncie ${ }^{44}$.

Na poziomie szkoły podstawowej tradycją są szkolne apele. Raz w miesiącu uczniowie i nauczyciele spotykają się w auli w celu nagrodzenia uczniów za ich pozytywne postawy, zachowanie oraz postępy w różnych dziedzinach nauki. Przede wszystkim jest to moment integracji zespołu, docenienia indywidualnych osiągnięć oraz okazja do tego, aby przedstawić efekty różnych projektów

${ }^{43}$ A. Radziwiłł, O szkole, wychowaniu i polityce, Warszawa 1993, s. 49.

${ }^{44}$ Wywiad z koordynatorem Szkoły Podstawowej Agnieszką Lal z 23.06.2014. 
i wydarzeń. Rozwój społeczny i dotyczący zdrowia wspierany jest przez program PSHE (Personal, Social and Health Education) ${ }^{45}$. Obejmuje on zagadnienia z zakresu rozwoju osobistego, współżycia w grupie oraz rozwija świadomość prowadzenia zdrowego trybu życia. W ramach tego programu co roku zapraszani są przedstawiciele różnych dyscyplin sportowych, promujących aktywność fizyczną oraz zdrowe odżywianie.

W tym kalejdoskopie różnic szkoła ma również wiele wspólnych celów, a jednym $\mathrm{z}$ nich jest wzajemna opieka. W placówce widoczna jest duża troska o uczniów, którzy zaczynają naukę w tak wyjątkowym środowisku, jakim jest SIS. Z końcem sierpnia, tuż przed rozpoczęciem nowego roku szkolnego, organizowany jest „Tydzień adaptacyjny dla nowych uczniów”. Zajęcia obejmują takie przedmioty, jak matematyka, język angielski i przyroda, ale jest to też dodatkowy czas dla nowo przybyłych, aby oswoić się z nową sytuacją szkolną, jak również zintegrować się z innymi uczniami. Nowi uczniowie napływają do szkoły także w takcie trwania roku szkolnego. Jest to związane z nowymi kontraktami dla żołnierzy z Korpusu, ale także z osiedlaniem się w Szczecinie nowych przedsiębiorców z różnych krajów. Dla uczniów i ich rodzin są to trudne chwile. Zderzenie z nowym środowiskiem i kulturą, bez znajomości języka, jest często szokiem i każdemu potrzebny jest czas na to, aby odnaleźć się w nowych warunkach. W tej szkole nowo przybyli są pod szczególną opieką zarówno nauczycieli, jak i rówieśników. Już od pierwszych chwil uwrażliwiamy młodych ludzi na zrozumienie i okazanie serdeczności. Aby wesprzeć, często zagubionego nowego ucznia, każdemu przydzielony jest „Guardian Angel”46. Aniołem jest uczeń (niekoniecznie z klasy), który służy zawsze pomocą i do którego nowo przybyły może się zwrócić z każdą prośbą. Z reguły nie ma problemu, aby znaleźć chętnego do podjęcia się takiego zadania. Opieką i zainteresowaniem otaczani są także członkowie rodzin. Często rodzice uczniów biorą udział w przygotowaniach do różnych szkolnych wydarzeń. Ponadto chętnie angażują się w procesy edukacyjne i sportowe. Takie relacje i współpraca korzystnie wpływają na obie strony. Rodzice mają szansę poczuć, że ich dzieci rozwijają się w warunkach wyjątkowych i zdobywają cenne umiejętności. Oprócz tego, sami przez swoje działanie tworzą środowisko wielokulturowe i są za nie współodpowiedzialni. Nauczyciele chętnie korzystają z pomocy i wsparcia rodziców, dzięki ich zaangażowaniu możliwe jest

\footnotetext{
${ }^{45}$ Tłum. Osobowościowa, Społeczna i Zdrowotna Edukacja.

46 Tłum. Anioł Stróż.
} 
zrealizowanie wielu wydarzeń i projektów w szkole, a także poza nią. Uczniowie są uwrażliwiani i kształtowana jest w nich postawa troski o innych ludzi i otaczający świat. Przykładem mogą być liczne akcje charytatywne, wspierające m.in. potrzebujące zwierzęta. Uczniowie SIS wzięli pod swoją opiekę konia Jaśmina, skazanego na rzeź ${ }^{47}$.

Powstawanie szkół niepublicznych po roku 1989 było determinowane różnymi czynnikami. Społeczeństwo chciało mieć wpływ na jakość kształcenia i wychowania młodych ludzi. Szkolnictwo niepubliczne definiowane było więc jako miejsce wolności, swobody myślenia i działania. Często szkoły tego typu wypełniały luki w polskiej oświacie spełniając potrzeby i oczekiwania uczniów i rodziców. Z czasem tworzenie takich placówek zaczęło wiązać się także z korzyściami finansowymi założycieli szkoły i chęcią utworzenia własnego biznesu. Szczecin International School, będąc szkołą stosunkowo młodą, bo niedawno obchodziła swoje dziesięciolecie, jest szkołą z misją, stworzoną dla potrzeb osiedlającego się wielokulturowego społeczeństwa w Szczecinie. W związku z tym jest dość obszerną skarbnicą wiedzy i doświadczeń dotyczących edukacji wielokulturowej i wykorzystywania języka obcego w celu poznania siebie i innych.

\section{Bibliografia}

Aleksander Z., Elementy lingworealioznawcze w nauczaniu j. rosyjskiego, Warszawa 1982.

Bartnik H., O wychowaniu, Szczecin 2012.

Bartnik P., Przemiany w zachodniopomorskiej oświacie (1989-2007), Szczecin 2012.

Demokracja w Polsce - doświadczenia zmian, red. U. Jakubowska, K. Skarżyńska, Warszawa 2005.

Górniewicz J., Szkoła a demokracja, „Wychowanie na Co Dzień” 1996, nr 6.

Górska L., Wizje zawodu nauczyciela u progu trzeciego tysiaclecia, Szczecin 1995.

Kiciński K., Wizje szkoły w społeczeństwach posttotalitarnych, Warszawa 1993.

Kozakiewicz D., Szkoła kolorowa - różnonarodowa, „Głos Szczeciński” 18-19.09.1999 r.

Lewowicki T., Przemiany w oświacie, Warszawa 1994.

Makowska M., Oświata niepubliczna jako forma aktywności obywatelskiej na Pomorzu Zachodnim po 1989 roku, Szczecin 2011.

Pomorze Zachodnie w latach 1945-2010, t. I, red. K. Kozłowski, Szczecin 2012.

Putkiewicz E., Wiłkomirska A., Szkoły publiczne i niepubliczne. Porównanie środowisk edukacyjnych, Warszawa 2004.

\footnotetext{
${ }^{47}$ Wywiad z koordynatorem Szkoły Podstawowej SIS, Agnieszką Lal z 23.06.2014.
} 
Radziwiłł A., O szkole, wychowaniu i polityce, Warszawa 1993.

Sapir E., Kultura, język, osobowość. Wybrane eseje, Warszawa 1978.

Szkoła, nauczyciele, uczniowie. Dyskusja o programie, metodzie i uczeniu się w Europie, red. T. Gomuła, T. Dyrda, Radom-Kielce 2010.

Szkołę tworzy człowiek, red. P. Migdalski, Szczecin 2012.

Szymański M.J., Szanse i bariery tworzenia demokratycznej szkoły we współczesnym społeczeństwie, Radom-Kielce 2010.

Śliwerski B., Problemy współczesnej edukacji. Dekonstrukcja polityki oświatowej III RP, Warszawa 2009.

Torenc M., Nauczanie międzykulturowe - implikacje glottodydaktyczne, Wrocław 2007.

W poszukiwaniu tożsamości. Od idei samorzadności do samorządzenia, red. A. Makowski, Szczecin 2011.

Wasilewski J., Ideał demokracji i jego ułomne wcielenia, Warszawa 2005.

\section{Akty prawne}

Deklaracja Programowa Społecznego Towarzystwa Oświatowego uchwalona przez I walne Zgromadzenie Członków Społecznego Towarzystwa Oświatowego z 22.01.1989 r., www.sto.org.pl/deklaracja-programowa.

Dz.U. MEN nr 7 z 1989 r. Zarządzenie w sprawie zasad prowadzenia pedagogicznej działalności innowacyjnej w szkołach i placówkach oświatowo-wychowawczych nr 62 z 16.11.1989 r.

Międzynarodowy Pakt Praw Gospodarczych, Społecznych i Kulturalnych otwarty do podpisu w Nowym Jorku dnia 19.12.1966 r., Dz.U. 1977, nr 38, poz. 169.

Obwieszczenie Przewodniczącego Rady Państwa z 16.02.1976 r. w sprawie ogłoszenia jednolitego tekstu Konstytucji Polskiej Rzeczypospolitej Ludowej uchwalonej przez Sejm Ustawodawczy z 22.07.1952 r., Dz.U. 1976, nr 7, poz. 36.

Ustawa o stowarzyszeniach z 7.04.1989 r., Dz.U. 1989, nr 20, poz. 104.

Ustawa o systemie oświaty z 7.09.1991 r., Dz.U. 1991, nr 95, poz. 425.

Wyrok NSA z 24.02.1989 r., I SA 1104/88, www.orzeczenia-nsa.pl/wyrok/i-sa1104-88,oswiata_szkolnictwo_wyzsze_nauka_dzialalnosc_badawczo_rozwojowa_i_archiwa,4calf4.html.

\section{Źródla internetowe}

International Primary Curriculum, www.greatlearning.com/ipc.

Raport firmy Sedlak \& Sedlak ukazuje zamożność w poszczególnych województwach. Mapa wynagrodzeń Polaków w 2010 roku, Kraków 2011, http://hrstandard.pl/download/RAPORT_Mapa_wynagrodzen_Polakow.pdf. 
Rocznik statystyczny Rzeczypospolitej Polskiej 2010. Oświata $i$ wychowanie w roku szkolnym 2009-2010, Warszawa, www.stat.gov.pl/cps/rde/xbcr/gus/PUBL_e_education_in_2009-2010_school_year.pdf.

Społeczne Towarzystwo Oświatowe, www.sto.org.pl/historia.

Urząd Miasta Szczecin, Wydział Oświaty, www.bip.um.szczecin.pl/umszczecinbip/ chapter_11026.asp.

\section{Archiwum szkolne}

Kroniki szkoły.

Lista uczniów w roku szkolnym 2012-2013.

Porozumienie wstępne z 20.07.2002 r. między Dowódcą Wielonarodowego Korpusu Północny Wschód (reprezentującym rodziców z Kwatery Głównej Korpusu), Zachodniopomorskim Kuratorem Oświaty, Prezydentem Miasta Szczecina a Wyższą Szkoła Integracji Europejskiej w sprawie utworzenia Międzynarodowej Szkoły w Szczecinie.

Program nauczania w gimnazjum SIS.

Program nauczania w liceum SIS.

Statut szkoły.

\section{Wywiady}

Wywiad z Agnieszką Lal, koordynatorem Szkoły Podstawowej SIS (z 23.06.2014).

Wywiad z Marią Hajdul, zastępcą dyrektora Wydziału Oświaty Urzędu Miasta w latach 1994-2001 (z 1.07.2014).

\section{The Teaching and Educational Activity of Szczecin International School in the Context of Private Educational System after 1989}

The author of the article proposes the following theses: political transformations enabled the democratisation of the Polish educational system and the creation of non-public (private) schools in Poland after 1989; the creation of the Educational Social Association initiated the creation of non-public schools in Poland; the creation of Szczecin International School (SIS) as a response to the needs of the market of the international community settling down in Szczecin; the activities of SIS, a school that runs an inter-cultural education; international programmes that make it possible to teach in a culturally diversified environment; familiarisation with another culture as a way to the acceptance, tolerance and understanding. 